\title{
The necessity for a new quality standard for freight transport and logistics in Europe
}

\author{
Dewan Md Zahurul Islam • Thomas H. Zunder
}

Received: 16 October 2012 / Accepted: 22 May 2014 / Published online: 5 June 2014

(C) The Author(s) 2014. This article is published with open access at SpringerLink.com

\begin{abstract}
Purpose The objectives of this paper are to: collect and analyse existing European international standards for freight transport and logistics quality; consult with industry actors and stakeholders in order to ascertain to what extent these quality standards (or quality labels) drive freight transport and logistics quality in practice and ascertain whether there is a need for a new or modified freight transport and logistics standard. The ultimate objective is to examine the extent to which new or existing, specialised, quality standards are useful as policy tools to improve the performance of freight transport and logistics service in Europe.

Methodology A multi-technique qualitative approach was applied consisting of desktop research, telephone interviews, two rounds of Delphi study and validation by an expert focus workshop.

Findings The research identified transport logistics relevant standards and analysed them, in particular the following six specialised freight transport and logistics standards (EN 13011: 2000, CEN/TR 14310: 2002, EN 13876:2002, EN 12507: 2005, EN ISO 9001:2000, EN 12798:2006, and EN 15696:2007) and three key ISO management standards: ISO 9001, ISO 14001 and ISO 28000. The research found that the (six) specialised freight transport and logistics standards are poorly known, but that ISO 9001 and ISO 140001 are known and are capable of managing logistics quality. It also found that ISO 28000 is being adopted and that quality is not solely derived from standards Conclusion Based on the research the following recommendations for policy makers are made: no market demand for new standards exists; a totally free market is not seen as a qualityimproving framework; where fair and free competition is not
\end{abstract}

D. M. Z. Islam $(\bowtie) \cdot$ T. H. Zunder

Freight Logistics Research Group, NewRail - Newcastle Centre

for Railway Research, University of Newcastle Upon Tyne, NE1

7RU England, UK

e-mail: dewan.islam@newcastle.ac.uk present, or is distorted, government intervention may be appropriate; the internalisation of externalities is seen as a state role; and that logistics quality is better determined between customer and provider.

Applicability of the research findings The findings are useful and applicable to European policy makers and service users and the research findings may not be applicable worldwide. The paper contributes to the field of freight transport and logistics quality standards by examining the existing specialised standards, their usage and the need or otherwise for new policy initiatives by the European Union.

Keywords Freight · Logistics · Policy · Europe · Quality · Delphi $\cdot$ International standards · Government intervention

\section{Introduction}

The scope of this research is to address, in the context of Europe, how useful are new, specialised, international standards for freight transport and logistics, as policy tools. The need for this policy research was identified by the EU Freight Transport Logistics Action Plan [18] which looked to achieve performance improvements by establishing "in consultation with the stakeholders, a core set of generic indicators that would best serve the purpose of measuring and recording performance in freight transport logistics chains (e.g. sustainability, efficiency etc.) to encourage a switch to more efficient and cleaner forms of transport and generally improve logistics performance.” ([18], P. 9.)

The European Union, from its creation as the , has had a strong tradition of market intervention. In the arena of transport it has previously used directives, which have force of law in all member states, to define air passenger rights in the Passengers Charter for Air Travel: "establishing common rules on compensation and assistance to passengers in the 
event of denied boarding and of cancellation or long delay of flights" [17]. In the area of rail freight, the EU began a process towards mandatory quality standards, such as the UIC -Freight Department [37]) authored: "Guide: Quality of rail freight transport". Also, the European Commission proposal for a regulation of compensation, in cases of non-compliance with contractual quality requirements for rail freight services, eventually led, in 2003, to the industry-led UIC/CER/CIT Freight Quality Charter [9]. Notably, in the latter case, the leading rail client organisation, the International Union of combined Road-Rail transport companies (UIRR), began as supportive of market intervention, but moved to a more liberal position as time progressed. Similarly, the European Commission, transitioning from an interventionist stance, in the 2001 White Paper on Transport [16], to the more laissez-faire approach of the 2006 mid term review [15], looked to researchers to answer the question: "To what extent are specialised, international standards useful for the quality performance of freight logistics in Europe?"

This research therefore approached the research question with the following goals:

- To collect and analyse existing European international standards for freight transport and logistics quality;

- To consult with industry actors and stakeholders in order to ascertain the extent to which these quality standards (or quality labels) drive freight transport and logistics quality in practice; and

- To ascertain whether there is a need for a new or modified freight transport and logistics standard.

The research was conducted to inform European Union policy makers within the context of that Union, as opposed to the more liberal policies of the USA, and was therefore intended to gather qualitative data from general, industrial or service-related companies and also logistics operators and carriers, as well as experts.

\section{Methodology}

In order to achieve the above-mentioned goals, a methodology was developed and followed. The approach consisted of the following three steps: (a) desktop research of definitions, context and policy; (b) two rounds of Delphi study, conducted online; and (c) validation of the results by an expert focus workshop.

\subsection{Desktop research}

The desktop research was developed from the previous cataloguing of international standards for logistics by the BestLog [5] and this was then followed by a series of unstructured telephone interviews with the key trade associations in
Brussels (e.g. European Logistics Association - ELA, European Intermodal Association - EIA) linked to logistics services - both service providers and major shippers and receivers. The final work consisted of: collection and analyses of relevant data, from international and European organizations, as well as stakeholders of freight transport and logistics; identification of segments for quality performance in freight transport and logistics and classification of existing standards and initiatives; evaluation of existing standards and initiatives, by obtaining stakeholder's opinions; identification and recommendations of priority segments, for quality performance in freight transport logistics, to be considered for standardization and further actions. The desktop research was enriched by telephone interviews with trade associations.

\subsection{Delphi survey}

The Delphi technique can be used for both quantitative and qualitative data and is an appropriate technique for collecting, aggregating and analysing the informed judgements of a group or panel of experts on previously identified issues. The technique provides unbiased input, as the researcher and experts never meet face to face, preventing the negative effects of group dynamics and peer pressure [25, 32]. The Delphi results were then validated with an expert group workshop using facilitated discussions, break out groups and mutual brainstorming.

A Delphi study starts with in-depth desktop research to identify the issues and problems in the field and a preliminary questionnaire is developed. Generally, a broad range of topics is examined in the first round and open-ended statements are included in the questionnaire [38]. More than one round is carried out and, in each round, a questionnaire is used. The number of rounds can vary from two to ten [11, 20], although most use two iterations (see next section). In the later rounds, a limited range of issues is explored in a more structured way [38]. However, iteration is usually determined according to the achievement of consensus by the panel. Even though iteration results in a certain level of improvement or refinement, in most Delphi studies the main improvements usually occur between the first and the second rounds $[4,12,30]$. After the second round, only a few studies show much further improvement [14]; some have found no improvement at all after the second round [22]. There has been some development of techniques to measure the stability of answers at a group [13] and individual level [10]; this seems better suited to studies with more than two rounds but, considering the time and resource limitation for this research, we chose to clearly define the process in advance and then use consensus tests to check for the degree to which we had agreed statements.

One of the major objectives of applying a Delphi study is to achieve consensus on some previous issues. On consensus, Stuter [34] contends that: "The Delphi Technique and 
consensus building are both founded in the same principle - the Hegelian dialectic of thesis, antithesis, and synthesis, with synthesis becoming the new thesis. The goal is a continual evolution to "oneness of mind" (consensus means solidarity of belief) - collective mind, the holistic society, the holistic earth etc.' (p.1). Thus, achieving a consensus is an important criterion in a Delphi study, although Saldanha and Gray [32] contend that the result of a Delphi study does not necessarily require the achievement of consensus. They do agree, however, that such a consensus serves a useful measure of the agreement among the panellists on a policy area. Hwang [24] contends that "consensus of opinion does not necessarily mean $100 \%$ agreement among the participants in the panel" (p.123). A number of studies (such as [1, 24-26]) accepted "consensus" as the majority of responses in their Delphi studies. Ariel [3] thinks that a Delphi study is an appropriate technique to steer a consensus and Kapoor [26] thinks that a Delphi technique seeks solutions to a complex problem by taking opinions of a diverse group of experts. Thus the overall aim of the study is to achieve a consensus among the participants. To determine whether or not a consensus has been achieved, any arbitrary figure could be used, although some justification should be made for it. [1,2, 26]. Kapoor [26], Abdel-Fattah [1]), Saldanha and Gray [32], Hwang [24] and Islam et al. [25] used the following formula of Average Percent of Majority Opinion (APMO), which will also be used in the present research, to find out the cut-off point for a consensus:

The main objective of the application of the APMO formula is to achieve consensus among participants. "Majority" refers to a greater than $50 \%$ agreement or disagreement with the statements in the Delphi survey. "Aggregate of Majority Agreements" refers to the summation of the majority agreements with the statements and the "Aggregate of Majority Disagreements" refers to the summation of the majority disagreements with the statements.

The advantages and disadvantages of the Delphi technique are noted below:

Advantages

- It elicits the views of panels of experts.

- It employs an iterative process of summarising, averaging and recycling panel member's views to encourage convergence on a consensus view.

- Panellists are given the opportunity to revise earlier answers in the light of the general opinions expressed by the panel as a whole.

- Information is collected by questionnaire and does not involve interviews or discussion.

- Members of the panel are guaranteed anonymity [28].

Disadvantages

- Delphi study can exaggerate the concept of expertise.
- The composition of the panel is seldom random, reflects the personal biases of the researchers and is not necessarily representative of specialist knowledge in the field.

- Anonymity relieves panel members of accountability and hence can lead to careless responses.

- By seeking consensus, Delphi surveys promote a conservative view of the future, discourage original thinking and suppress radical views.

- It can have the effect of reinforcing existing paradigms.

It offers little insight into the reasoning underlying the panel member's responses and gives no opportunity for their arguments to be tested in face-to-face discussion [28].

Following consideration of the above discussed advantages and disadvantages it was decided to adopt the Delphi technique for the current research.

\subsection{Expert workshop}

The expert focus validation workshop was held in Paris and was attended by key actors from the logistics service sector and shippers (see Table 1). Following selection of a broad section of key stakeholders, the research partners invited one person from each company/organisation to participate.

The validation workshop presented the participants with the results of the research up to that point (i.e. desktop research, interviews, two rounds of Delphi study) and then split the group into two syndicates, each with a facilitator. Each syndicate was asked to discuss and then provide feedback, both on the research presented and also on any matters they felt had been omitted, so far.

\section{State of the Art}

The countries of the European Union practise a regulated market economy, wherein competition forms an important element. [27] (P.849) noted that the term "competitiveness": 'refers to the capacity of firms to compete and, on the basis of their success or "competitiveness", to gain market share (s), increase their profits and grow.' In the global market, companies compete with each other. The competition can be at company level, sector level or inter-country. For example, freight transport service providers compete with each other in the freight market. In the competitive environment, Liu et al. [27] p.860) suggest that diversified logistics service offerings are required to support the process of value creation. Competition between logistics service providers (LSPs) manifests competitive edge in these value added service offerings. Within the freight transport market there is inter-modal (sector level) competition; for example, trucking companies competing with rail freight transport operators. Competition can be 
Table 1 Expert focus group taken part in the validation workshop

\begin{tabular}{llll}
\hline Company & Type of activity & Management level & Country \\
\hline SNCF & Rail freight transport & Mid-management & France \\
AD REM JSC & Logistics service provider & Top-management & Lithuania \\
Binnenlandse Container Terminals Nederland b.v. & Terminal operator & Mid-management & The Netherlands \\
DB Schenker & Railway freight transport & Mid-management & Germany \\
DP World Southampton & Terminal operator & Mid-management & UK \\
Ellis International Transport Consulting Ltd & Transport consultancy & Top-management & UK \\
International LKW WALTER Transportation Av & Freight transport service provider & Top-management & Austria \\
HIDC & Logistics service provider & Top-management & The Netherlands \\
IFB & Logistics service provider & Operational -management & UK \\
Port Authority of Gijon & Terminal operator & Operational -management & Spain \\
Rockwool International & Shipper & Mid-management & Belgium \\
Zaragoza Logistics Center & Logistics service provider & Operational -management & Spain \\
\hline
\end{tabular}

between trucking companies registered in one European country, who operating Europe wide. In such a case, trucking operators may face discrimination, or experience unfairness. For example, road hauliers in the UK and in France complain that, due to the higher fuel tax in these countries, their national trucking companies face unfair competition versus Eastern European registered trucking companies. Thus the governments (or a regional body, such as the EC) can play a crucial role in establishing a free and fair competitive market. In the case of higher fuel duty in the UK, or in other Western European countries, the state may intervene. This raises questions about whether, or to what extent, the state should intervene to favour or discriminate against certain companies and, if so, which?

Sohal et al. [33] p.267) suggest that: "the effective implementation of quality management practices leads to improvements in organisational performance in terms of increased productivity and profits". The purpose of the European Committee for Standardisation (CEN) is to facilitate improvements in European businesses, by removing trade barriers for European industry and consumers. Its aim is to promote the European economy in global trading and to protect the welfare of European citizens and the environment. It provides a platform for the development of European Standards and other technical specifications and is the only recognised European organisation permitted to plan, draft and adopt European Standards in all areas of economic activity (except electro-technology and telecommunications) (according to Directive 98/34/EC). Uniquely, these standards are also national standards in each of CEN's 31 member countries. Under the terms of the Vienna Agreement (signed in 1991 with ISO - International Organisation for Standardisation) technical cooperation by correspondence, mutual representation at meetings and coordination meetings, and adoption of the same text, are ensured to be both an ISO standard and a European Standard.
CEN defines a standard as a technical document that is designed to be used as a rule, a guideline or a definition. It is a consensus built, repeatable way of doing something. Standards are created by bringing together all interested parties, such as manufacturers, consumers and regulators of a particular material, product, process, or service. All parties benefit from standardisation, through increased product safety and quality, as well as lower transaction costs and prices. ISO9001, ISO140001 [35] and ISO 28000 [7] are well known, process-based and certifiable standards applicable in industry and with an impact on quality, sustainability and security. FabbeCostes et al. [19] think that "standards facilitate market transactions by making it easier to exchange information and provide opportunities for mass production --. They create a common language between the adopters, reduce the transaction costs -- and also allow for large economies of scale".

Logistics quality can be "defined in terms of performance 'gaps' and is measured as the ability to distribute a product or materials in conformance with customer requirements and standards" ([29] p 350). On the other hand, there are several definitions of quality. The ISO 8402-1986 standard defines quality as "the totality of features and characteristics of a product or service that bears its ability to satisfy stated or implied needs." Quality can be defined as "conformance to requirement" and/or "fitness for use" and/or "the degree of conformance to a standard" and/or "user satisfaction" ([23] p.51). The Quality Manual for Combined Transport UIC 2001 also associates with this, as it defines quality as "an underlying part of each product that we identify as a service; it is a guarantee of adherence to what was agreed upon. Indeed, the concept actually goes one step further; quality implies a match between the customer's requirements and the service-provider's 
technical capacity". Thus standards are intimately connected with quality and vice versa and we can say that:

- Quality is always relative to a set of inherent characteristics and a set of requirements;

- Quality is a question of degree to which the product or service meets the customer'sxpectations.

Padilla et al. [31] suggest that, as a differentiation and quality management tool, an official certified quality label is a good alternative to certification, to improve the situation and market opportunities for small farmers. 'Labelling' refers to describing something in words, or a short phrase, while 'certification' refers to the confirmation of certain characteristics of an object, person, or organisation, often by some form of external review, education, assessment, or audit. An example of a label is the GS1 Logistics Label: Standard International Logistic Label - STILL [21]; an example of a certificate would be that issued by TÜV or BSI after an ISO90001 audit. During our desktop research (supported by the interviews with industry associations) we realised that a quality standard model based on the Passengers Charter for Air Travel is not appropriate for freight, since transport and logistics clients are more knowledgeable about the parameters than are travellers in the air passenger sector. Also, in this context, quality is not a fixed variable in commercial matters, but rather a synthesis of price and service, with service being a multi-varied entity in itself.

The BestLog (Best Practices in Logistics) project ([5, 6 p.28]) identified a total of 52 certificates and suggested that Labelling and/or Certification is beneficial to the direct stakeholders for the following important reasons:

- Easier relationships with suppliers;

- Guarantee of functionality along the Supply Chain;

- The standardisation of employee training, allowing staff rotation;

- European certificate for Logistics Professionals, - a way to excellence which covers all sustainability dimensions (social, environmental and economic);

- All members of the company benefit from the Label or Certification by meansof the application of best practice principles; and

- Market advantage for a certified company from a Label/ Certificate by means of economic savings, environmental and social responsibility and, finally, customer satisfaction.

The BestLog [5] project warned that the research in the field of certification programmes is far more complex than they initially expected. Hence the detection of additional certificates with a logistics focus is very difficult. Although certificates are created by organisations such as the International Organization for Standardisation (ISO), the certificates themselves are mostly granted by licensed companies or associations, which make the collection of logistics certificates very difficult. These companies often also alter official certificates to customise them to special sectors or fields. Furthermore, many national certificates have been adapted to European certificates, making differentiation complicated. Additionally, many certificates affect logistics indirectly, making clear classification even more complicated. All in all, the project found a high diversity of certifications in the market, with an ambiguous degree of focus.

With this in mind this research focused on six freight transport and logistics standards; then on opinions and trends with regard to different standardisation approaches, for example voluntary agreement between parties; and on the need for new standards [36].

\section{Results}

\subsection{Results from desktop research and interviews}

From the desktop research we adopted a definition of freight transport and logistics quality as follows: "The degree to which the performance of the freight transport operations, across modes in the supply chain, meets stated service criteria". This definition was used to start the research process and was redefined as a part of the study.

Through literature reviews followed by informal interviews with a relevant expert, this research identified 14 valid standards [8] relevant to transport and logistics (see table 2), all developed in the European Committee for Standardisation (CEN) Technical Committee (TC) (CEN/TC) 320, responsible for Transport - Logistics and Services, of which six standards (highlighted in Italic font) are of significant interest for the whole supply chain. The research considered standards or labels to be of significant interest if they can be used for the whole supply chain. Further to this, with the support of the interviewees, 32 initiatives addressing quality performance in transport logistics, launched by different transport actors and operators (involving all transport modes), have been collected and analysed. (Not listed in this paper due to word and space limitations). Table 2 includes two ISO standards that are not aimed directly at logistics, but these are considered for the study as they aim to improve business process where logistics and supply chain come into consideration.

\section{Profile of Delphi panel}

The panel was selected from a pool of over 1200 freight and logistics contacts held by the authors and additional persons nominated by other research partners. The panel was therefore 
Table 2 List of identified transport and logistics relevant standards (Source: compiled by the Authors)

\begin{tabular}{|c|c|c|c|}
\hline Standard name & $\begin{array}{l}\text { Regulating } \\
\text { organisation }\end{array}$ & $\begin{array}{l}\text { Issue } \\
\text { Year }\end{array}$ & Scope \\
\hline CEN/TR 14310 & CEN & 2002 & $\begin{array}{l}\text { Freight transportation services - Declaration and reporting of environmental performance in } \\
\text { freight transport chains. }\end{array}$ \\
\hline $\begin{array}{l}\text { EN } 12507 \text { EN - Européen } \\
\text { de Normalisation }\end{array}$ & CEN & 2005 & $\begin{array}{l}\text { Transportation services - Guidance notes on the application of EN ISO 9001:2000 to the road } \\
\text { transportation, storage, distribution and railway goods industries. }\end{array}$ \\
\hline EN 12522-1 & CEN & 1998 & $\begin{array}{l}\text { Furniture removal activities - Furniture removal for private individuals - Part 1: Service } \\
\text { specification }\end{array}$ \\
\hline EN 12522-2 & CEN & 1998 & $\begin{array}{l}\text { Furniture removal activities - Furniture removal for private individuals - Part 2: Provision of } \\
\text { Service }\end{array}$ \\
\hline EN 12798 & CEN & 2007 & $\begin{array}{l}\text { Transport Quality Management System - Road, Rail and Inland navigation transport - Quality } \\
\text { management system requirements to supplement EN ISO } 9001 \text { for the transport of } \\
\text { dangerous goods with regard to safety }\end{array}$ \\
\hline EN 13011 & CEN & 2000 & $\begin{array}{l}\text { Transportation services - Good transport chains - System for declaration of performance } \\
\text { conditions }\end{array}$ \\
\hline EN 13816 & CEN & 2002 & $\begin{array}{l}\text { Transportation - Logistics and services - Public passenger transport - Service quality definition, } \\
\text { targeting and measurement }\end{array}$ \\
\hline EN 13876 & CEN & 2002 & $\begin{array}{l}\text { Transport - Logistics and Services - Goods transport chains - Code of practice for the provision } \\
\text { of cargo transport services }\end{array}$ \\
\hline EN 14873-1 & CEN & 2005 & $\begin{array}{l}\text { Furniture removal activities - Storage of furniture and personal effects for private individuals - } \\
\text { Part 1: Specification for the storage facility and related storage provision }\end{array}$ \\
\hline EN 14873-2 & CEN & 2005 & $\begin{array}{l}\text { Furniture removal activities - Storage of furniture and personal effects for private individuals - } \\
\text { Part 2: Provision of the service }\end{array}$ \\
\hline EN 14892 & & 2005 & Transport service - City logistics - Guideline for the definition of limited access to city centers \\
\hline EN 14943 & CEN & 2005 & Transport services - Logistics - Glossary of terms \\
\hline EN 15140 & CEN & 2006 & $\begin{array}{l}\text { Public passenger transport - Basic requirements and recommendations for systems that } \\
\text { measure delivered service quality }\end{array}$ \\
\hline EN 15696 & CEN & 2008 & Self storage - Specification for self storage services \\
\hline ISO 9001 & ISO & 2008 & $\begin{array}{l}\text { Quality management systems - Requirements. GetISO (2012) reports that it includes the } \\
\text { following eight core principles: improved consistency with traceability; enhanced customer } \\
\text { focus; focused leadership; involvement of people; a system approach to management; } \\
\text { continual improvement; a factual approach to decision making; and mutually beneficial } \\
\text { supplier relations. }\end{array}$ \\
\hline ISO 14001 & ISO & 1996 & $\begin{array}{l}\text { Environmental management systems - Requirements with guidance for use. The ISO } 14000 \\
\text { Environmental Management Group (2002) suggests that this standard is applicable to any } \\
\text { organisation that wishes to: implement, maintain and improve an environmental } \\
\text { management system;assure itself of its conformance with its own stated environmental } \\
\text { policy (those policy commitments of course must be made); demonstrate conformance; } \\
\text { ensure compliance with environmental laws and regulations; seek certification of its } \\
\text { environmental management system by an external third party organization make a self- } \\
\text { determination of conformance. }\end{array}$ \\
\hline ISO 28000 & ISO & 2007 & $\begin{array}{l}\text { Specification for security management systems for supply chain. The Bureau Veritas (2012) } \\
\text { reports 'ISO } 28000 \text { was developed in response to the transportation and logistics industries' } \\
\text { need for a commonly applicable security management system specific to supply chain } \\
\text { security. However, companies in many other industries are finding it useful to assess } \\
\text { security risks, implement controls, and mitigate arrangements to manage potential security } \\
\text { threats and impacts on the supply chain. Quality, safety and customer satisfaction also } \\
\text { benefit from this management system. The requirements for ISO } 28000 \text { include all critical } \\
\text { aspects for supply chain security assurance'. }\end{array}$ \\
\hline
\end{tabular}

self-selecting, which is in line with accepted practice (e.g. [28], p. 3). It is probable that the panel self-selected on the basis of professional or personal links to the researchers, or each other, but this was not tested and is conjecture. A total of 100 participants took part in the first round Delphi survey, of which 90 are valid. The reasons for invalid responses are: duplication and response from research partners. The valid participants comprised $44 \%$ senior (executive) managers, $40 \%$ middle managers and $16 \%$ operational or junior management. Typically, the senior managers are responsible for developing policies and for controlling and overseeing the entire organisation, while the middle managers are responsible 
for executing organisational plans, in line with the company's policies. The junior managers focus on controlling, directing and supervising the activities of employees. The first round Delphi panel was made up of: transport or logistics service providers $40.3 \%$; transport or logistics service users $9 \%$; research organisation in the field $33 \%$; trade association $4.5 \%$; policy makers $6.5 \%$; and 'other' $6 \%$.

Of these, $61 \%$ had more than ten years experience, $58 \%$ belonged to small to medium enterprises (SMEs) and $37 \%$ were transport or logistics service providers. A total of 48 validated participants took part in the second round Delphi. It can be noted here that, as a Delphi study norm, the second round survey is restricted to the participants of the first round Delphi survey (i.e. among the valid 90). ${ }^{1}$ In the second round the panel was made up of $52 \%$ senior (executive) managers, $40 \%$ middle managers and $8 \%$ operational or junior management. Of these, $69 \%$ had more than ten years experience, $46 \%$ belonged to SMEs and $36 \%$ were transport or logistics service providers. Of the SMEs, $41 \%$ were from research organisations (academic, consultancy, research centre) and $27 \%$ from transport or logistics service providers. Around $73 \%$ of the participants with $10+$ years of experience belonged to SMEs.

The highest number of responses, in both rounds, came from (in descending order): United Kingdom, Netherlands, Germany, Austria, Belgium and France. The dominance of a few countries was not viewed as problematic, since logistics is an international business and we were studying international standards; profile (e.g. experience in relevant field, management level) was therefore viewed as more significant than geography.

\subsection{Findings from Delphi study}

Applying the APMO formula, the consensus point for both Round 1 and Round 2 was $64 \%$.

\subsection{Degree of widespread knowledge of standards}

The first round of Delphi survey posed three questions: whether these (marked in Italic) quality standards are known by the experts; their usage (low, medium and high); and their strengths and weaknesses. It was found that the existing logistics standards were not well known by the Delphi panel. In contrast, they said that the ISO 9001 (Quality management systems requirement) and ISO 14001 (Environmental management systems requirements with guidance for use) are more known to them and that these two standards have higher usage.

\footnotetext{
${ }^{1} 64$ responses were made. Non-valid responses were: duplication; core questions being incomplete.
}

\subsection{Definition of logistics quality standard}

During the desktop research the researchers found that there is no definition of transport logistics quality. A definition was therefore proposed, in the first round, and a consensus was reached that "Transport logistics quality can be defined as the degree to which the performance of the freight transport operations, across modes in the supply chains, meets stated service criteria." The Delphi panel added some statements that were included in the second round and the level of agreement on these statements in the second round survey is shown in Table 3. From these responses we can deduce that "Transport logistics quality can be defined as the degree to which the performance of the freight transport operations, across modes in the supply chains, meets stated service criteria, and should incorporate the elements of reasonable price, transit time, punctuality, reliability and sustainability." The addition of sustainability is clear, which raises questions about definition, but these have been defined and arbitrated elsewhere in research and government level initiatives. Note the use of the word "should", which is normative, but does not confirm current practice or any compulsion. Later statements enlarged these ideas.

\subsection{Logistics quality standard requirement}

In the first round, the statement that achieved a consensus was "Logistics quality standard requirement should be set by the market." The Delphi panel added some statements that are included in the second round and the level of agreement on these statements is shown in Table 4. From this we state that "Logistics quality standard requirement should be set by the market between client and provider within a regulatory framework that reflects the externalities of transport and logistics."

\subsection{Role of voluntary agreements}

In the first round the statement consensus was reached that "Logistics quality standards should be implemented by Voluntary agreement between parties." The Delphi panel added some statements that are included in the second round and the level of agreement on these statements is shown in Table 5. From these responses we state that: "Logistics quality standards should be implemented by voluntary agreement between parties as currently, within minimum environmental and security levels determined by government. Small users may not be aware of what to demand."

\subsection{Need for state intervention}

The statement "The logistics industry needs state intervention to improve logistics service quality" did not achieve consensus in the first round. The Delphi panel added some statements 
Table 3 Second round Delphi panel on the definition of logistics quality standards

\begin{tabular}{llc}
\hline Delphi Panel Added Statements on the definition of logistics quality standards & $\begin{array}{l}\text { Agreement } \\
\text { Level }\end{array}$ & $\begin{array}{l}\text { Achieved } \\
\text { Consensus? }\end{array}$ \\
\hline $\begin{array}{l}\text { Transport logistics quality means to what degree the performance of a product or } \\
\text { service meets the expectations of the customer/client. }\end{array}$ & $89.6 \%$ & Yes \\
$\begin{array}{c}\text { Transport logistics quality should take into account of sustainability, reliability, } \\
\text { efficiency and cost }\end{array}$ & $85.4 \%$ & Yes \\
$\begin{array}{c}\text { Transport logistics quality means meeting service criteria agreed between client } \\
\text { and service provider across modes in the supply chains effectiveness }\end{array}$ & $79.2 \%$ & Yes \\
$\begin{array}{c}\text { Transport logistics quality means a perfect combination of reasonable price, transit } \\
\text { time, punctuality and reliability }\end{array}$ & $75.0 \%$ & Yes \\
$\begin{array}{c}\text { Transport logistics quality means the level required by the market and reached by } \\
\text { using a complete supply chain of services }\end{array}$ & $58.3 \%$ & No \\
\begin{tabular}{c} 
Transport logistics quality optimizes transport efficiency across all modes \\
\hline
\end{tabular} & $56.3 \%$ & No \\
\hline
\end{tabular}

that were included in the second round and the level of agreement/disagreement about these statements is shown in Table 6. From these responses we state that: "National governments and the European Commission could play a role in facilitating quality improvements through projects; direct State intervention often results in distortion of the competitive market; indirect State intervention (e.g. transport infrastructure improvements, addressing modal imbalances through internalisation of external costs) can result in improvements without market distortion."

\subsection{Free and fair competition}

In the first round Delphi, consensus was reached on the statement "Free and fair competition is the only way to improve logistics service quality." The Delphi panel added some statements that were included in the second round survey and the level of agreement on these statements is shown in Table 7. These responses lead us to state (with some internal contradictions) that: "Free and fair competition is one way to improve logistics service quality; the market should reflect the basic externalities; state incentives should be allowed to enhance sustainable transport but, the market does not necessarily respond to provide the best solutions when unfettered." This is so contradictory and at odds with the results from the first round panel statement, that some care needs to be taken with it.

\subsection{Transport logistics systems trust}

The statement "We can only trust transport logistics systems through quality contracts" did not achieve consensus in the first round. The Delphi panel added some statements that were included in the second round survey and the level of agreement about these statements is shown in Table 8. These consensus statements lead us to suggest the statement: "Contracts should include key performance indicators (KPIs), but quality can not be managed only by key performance indicators - it is a philosophy of work. It is not possible to put all quality requirements in a contract."

\subsection{Quality labels}

The role of the Quality Label can be performed by the certification of quality standards provided by a relevant authority. The statement "Quality labels are only marketing tools" did
Table 4 Second round Delphi on the logistics quality standard requirement

\begin{tabular}{lll}
\hline Delphi Panel Added Statements logistics quality standard requirement & $\begin{array}{l}\text { Agreement } \\
\text { Level }\end{array}$ & $\begin{array}{l}\text { Achieved } \\
\text { Consensus? }\end{array}$ \\
\hline $\begin{array}{l}\text { Quality standards should be set by service provider and user(shipper/ } \\
\text { consignee }\end{array}$ & $72.9 \%$ & Yes \\
$\begin{array}{l}\text { This should include the externalities of transport and logistics services for } \\
\text { the wider community. So the regulatory authority needs to determine the } \\
\text { externalities and hence the framework for operation and within this the } \\
\text { market should then set the quality standard. }\end{array}$ & $64.6 \%$ & Yes \\
$\begin{array}{l}\text { Logistics quality standard requirement should be set Contractually between } \\
\text { partners. However, in the case of substantial disparity between partners } \\
\text { (supplier/client) regulatory interference might be advisable to secure } \\
\text { common base standards }\end{array}$ & $60.4 \%$ & No \\
$\begin{array}{l}\text { Legislators cannot be involved in devising standards to which the logistics } \\
\text { industry should perform }\end{array}$ & $39.6 \%$ & Divided Opinion \\
$\begin{array}{l}\text { If the market does not succeed to set appropriate, measurable and realistic } \\
\text { standards, the government should take this responsibility }\end{array}$ & $37.5 \%$ & Divided Opinion \\
\hline
\end{tabular}


Table 5 Second round Delphi panel on the logistics quality standard implementation

\begin{tabular}{|c|c|c|}
\hline Delphi Panel Added Statements logistics quality standard implementation & $\begin{array}{l}\text { Agreement } \\
\text { Level }\end{array}$ & $\begin{array}{l}\text { Achieved } \\
\text { Consensus? }\end{array}$ \\
\hline $\begin{array}{l}\text { Some standards regarding security and environment should have a minimum } \\
\text { level set by state legislation to create an even market level playing field. }\end{array}$ & $81.3 \%$ & Yes \\
\hline $\begin{array}{l}\text { Logistics quality standards are already implemented in terms and agreements } \\
\text { between service providers and users. The issue is not implementation, } \\
\text { but awareness of what may be demanded by users, particularly small ones. } \\
\text { The big ones know what to demand. }\end{array}$ & $64.6 \%$ & Yes \\
\hline The voluntary agreement should be defined by the provider & $39.6 \%$ & Divided Opinion \\
\hline $\begin{array}{l}\text { There should be a minimum level implemented by European legislation } \\
\text { and the extra need of customers should be dealt with by voluntary } \\
\text { agreement }\end{array}$ & $47.9 \%$ & Divided Opinion \\
\hline
\end{tabular}

not achieve consensus in the first round. The Delphi panel added some statements that were included in the second round survey and the level of agreement about these statements is shown in Table 9. From the new consensus we derive the statement: "Quality labels and indicators (e.g. carbon footprints) can result in behavioural change; they have to be renewed and audited by the company to constantly monitor their processes; marketing and sourcing is a key role, but labels are not the single determinant, if what these certificates promise is not reflected in day to day operations."

\subsection{Elements of quality standards}

During the prioritisation of the elements of quality standards, the Delphi panel added some statements that were included in the second round survey and the level of agreement is shown in Table 10. From these we derive the statement that: "The weakest points of the supply chain are the information flows, especially in the case of deviations in good time to the right recipient; solving this could contribute to a more efficient service at the interfaces of the supply chain; it is a negotiated service/quality level and specific price that matters most."

\subsubsection{Need for a new standard}

The Delphi panel was divided on the statement: "There is a need for a new or modified standard in the transport and logistics field." The Delphi panel added some statements that were included in the second round and the level of agreement/ disagreement about these statements is shown in Table 11. None of these statements achieved majority agreement or disagreement consensus. It can be noted that a significant number of the panel opted for the 'No Comment' opinion. This may indicate the level of sensitiveness around the issue.

At all stages (i.e. desktop research and interviews with experts; two rounds of Delphi study; a validation workshop)
Table 6 Second round Delphi on the state intervention to improve logistics quality

\begin{tabular}{lll}
\hline $\begin{array}{l}\text { Delphi Panel Added Statements state intervention to improve logistics } \\
\text { quality }\end{array}$ & $\begin{array}{l}\text { Agreement } \\
\text { Level }\end{array}$ & $\begin{array}{l}\text { Achieved } \\
\text { Consensus? }\end{array}$ \\
\hline $\begin{array}{l}\text { Direct State intervention often results in distortion of competitive market. } \\
\text { Indirect State intervention (e.g. transport infrastructure improvements, } \\
\text { addressing modal imbalances through internalisation of external costs) }\end{array}$ & $68.8 \%$ & Yes \\
$\quad$ can result in improvements without market distortion. \\
$\begin{array}{l}\text { State intervention is a strong expression - national governments and the } \\
\quad \text { European Commission could play a role in facilitating quality } \\
\text { improvements through projects }\end{array}$ & $66.7 \%$ & Yes \\
$\begin{array}{l}\text { If state intervention is invoked, more effort will be spent fighting the issue } \\
\text { than improving service quality. }\end{array}$ & $52.1 \%$ & No \\
$\begin{array}{l}\text { Infrastructure provision is a monopoly and therefore requires state } \\
\text { intervention }\end{array}$ & $52.1 \%$ & No \\
$\begin{array}{l}\text { Let the State focus on crime, maximum loading weight, working hours } \\
\text { etc., but not on quality }\end{array}$ & $52.1 \%$ & No \\
$\begin{array}{l}\text { The markets should regulate themselves } \\
\text { In the case of substantial disparity between partners (supplier/client) } \\
\text { regulatory interference might be advisable to secure common base } \\
\text { standards. }\end{array}$ & $50.0 \%$ & No \\
$\begin{array}{l}\text { State intervention may be needed to protect the SMEs and prevent severe } \\
\text { externalities of transport and logistics services }\end{array}$ & $43.8 \%$ & Divided Opinion \\
\hline
\end{tabular}


Table 7 Second round Delphi panel on the free and fair market place for logistics quality

\begin{tabular}{|c|c|c|}
\hline $\begin{array}{l}\text { Delphi Panel Added Statements the free and fair market place for logistics } \\
\text { quality }\end{array}$ & $\begin{array}{l}\text { Agreement } \\
\text { Level }\end{array}$ & $\begin{array}{l}\text { Achieved } \\
\text { Consensus? }\end{array}$ \\
\hline $\begin{array}{l}\text { The most important issue is to ensure a common level playing field for all } \\
\text { participants in the market }\end{array}$ & $89.6 \%$ & Yes \\
\hline Fairness has to be stressed e. g. regarding internalisation of external cost. & $77.1 \%$ & Yes \\
\hline $\begin{array}{l}\text { The market does not necessarily respond to provide the best solutions when } \\
\text { unfettered }\end{array}$ & $75.0 \%$ & Yes \\
\hline $\begin{array}{l}\text { Free and fair competition' is important and a prerequisite, but not the 'only' } \\
\text { way }\end{array}$ & $75.0 \%$ & Yes \\
\hline State incentives should be allowed to enhance sustainable transport & $75.0 \%$ & Yes \\
\hline The market ought to be fair and reflective of least externalities & $72.9 \%$ & Yes \\
\hline
\end{tabular}

the experts consulted were divided on the final issue: whether or not a new or modified standard is needed. However, no clear pressing need for one emerged.

\subsection{Findings of the expert focus workshop}

The workshop reported that the Delphi study methodology successfully explored the logistics quality issues. The findings of the study represent a high level of research outputs. The workshop participants agreed that fair and free competition is a prerequisite for quality, but they also warned that a total deregulation is not wanted. Existing freight transport and logistics quality standards are hardly known (similar to the findings of the Delphi study) and thus a step is needed to make them known to the users. Also as found in the Delphi study, ISO 9001 \& ISO 14001 are considered to be widely known and used by service providers and users, but these ISO standards are process oriented. They do not include some important aspects such as the quality definition and the meeting of stated service criteria (or KPIs). The workshop participants advocated standards such as the industry-led Safety \& Quality Assessment System (SQAS), which is a standard to evaluate the quality, safety, security and environmental performance of Logistics Service Providers (LSP's) and Chemical Distributors, in a uniform manner, by single standardised assessments carried out by independent assessors, using a standard questionnaire. They stated that quality is better determined by a contract between customer and provider, not the whole supply chain, and that clearly defined KPIs are essential for such contracts.

\section{Discussion}

The current research conducted desktop research, interviews with experts, two rounds of Delphi study and validation workshop with industry actors, to achieve the following three goals: collect and analyse existing European international standards for freight transport and logistics quality; consult with industry actors and stakeholders in order to ascertain to what extent these quality standards (or quality labels) drive freight transport and logistics quality in practice; and ascertain whether there is a need for a new or modified freight transport and logistics standard. The desktop research and interviews
Table 8 Second round Delphi panel on the trust and quality contracts

\begin{tabular}{|c|c|c|}
\hline Delphi Panel Added Statements on the trust and quality contracts & $\begin{array}{l}\text { Agreement } \\
\text { Level }\end{array}$ & $\begin{array}{l}\text { Achieved } \\
\text { Consensus? }\end{array}$ \\
\hline Contracts should include key performance (quality) indicators (KPIs) & $79.2 \%$ & Yes \\
\hline Trust is very important but remains unstated in a contract & $77.1 \%$ & Yes \\
\hline $\begin{array}{l}\text { Quality must be a philosophy of work. It is not possible to put all } \\
\text { quality requirements in a contract }\end{array}$ & $68.8 \%$ & Yes \\
\hline $\begin{array}{l}\text { At the end of the day it is the actual level of quality that is provided } \\
\text { which counts and not the content of individual contracts. }\end{array}$ & $64.6 \%$ & Yes \\
\hline $\begin{array}{l}\text { Quality cannot only be managed by KPI's. It mainly has to do with } \\
\text { the service and response you get when something out of the ordinary } \\
\text { happens. How flexible and willing is a party at that time to deliver } \\
\text { service and quality. Outside the contract occurrences give you a } \\
\text { much better insight. }\end{array}$ & $64.6 \%$ & Yes \\
\hline Quality contracts must be in place for all and every transport mode & $52.1 \%$ & No \\
\hline $\begin{array}{l}\text { Don't be chained by contracts, use the freedom to provide or receive } \\
\text { better transport logistics systems }\end{array}$ & $35.4 \%$ & Divided Opinion \\
\hline
\end{tabular}


Table 9 Second round Delphi panel on the quality label as a marketing tool

\begin{tabular}{lll}
\hline Delphi Panel Added Statements on the quality label as a marketing tool & $\begin{array}{l}\text { Agreement } \\
\text { Level }\end{array}$ & $\begin{array}{l}\text { Achieved } \\
\text { Consensus? }\end{array}$ \\
\hline They can be used as requirements when sourcing services & $83.3 \%$ & Yes \\
$\begin{array}{l}\text { With an effective audit system in place, it can be proven as 'capable and in control' } \\
\text { Clients could ask to have quality label as mandatory, especially in high volume } \\
\text { tenders }\end{array}$ & $77.1 \%$ & Yes \\
$\begin{array}{l}\text { Marketing is a dominant aspect. But quality label can play an important role. } \\
\text { Quality labels and indicators (e.g. carbon footprints) can result in behavioural } \\
\quad \text { change }\end{array}$ & $77.1 \%$ & Yes \\
$\begin{array}{l}\text { Quality labels have to be cared for/renewed - this is forcing the company to } \\
\quad \text { constantly monitor their processes }\end{array}$ & $75.0 \%$ & Yes \\
$\begin{array}{l}\text { Useful indicator, but not the single determinant. All too often a certificate is } \\
\text { relatively easy to obtain, while day to day operations are not fully reflected } \\
\text { by what these certificates promise }\end{array}$ & $72.9 \%$ & Yes \\
\hline
\end{tabular}

with experts resulted in a questionnaire for the first round of Delphi study. Two further rounds of Delphi study, using an online survey tool, were then conducted. The findings of the Delphi study were validated by a workshop whose participants were industry actors. The study identified and analysed existing EU-wide standards in freight transport and logistics quality from CEN and also identified national initiatives. The research finds that:

- $\quad$ These European international standards for freight transport and logistics quality are known to few users;

- A key weakness is their lack of dissemination; the lack of transparency at CEN does not help;

- That ISO 9001 and ISO140001 are capable of managing quality and are used as such;

- That ISO 28000 standards regarding supply chain risk appear to be emerging as equal to the former to form a virtuous trinity and
- That quality is not solely derived from standards, but more from customer-client relationships, and even more so from culture and process.

Our research also finds that:

- Direct state intervention for a new or modified standard is not wanted, but a totally free market is not seen as a quality-improving framework;

- That government has an important role to ensure fair and free competition that is a prerequisite for quality standards; where fair and free competition is not present or distorted, intervention may be appropriate;

- That the internalisation of externalities is seen as a part of the basic state role in the market;

- Quality is better determined by a contract between customer and provider, not for the whole supply chain;
Table 10 Second round Delphi panel on the elements/segments of quality standards

\begin{tabular}{llc}
\hline $\begin{array}{l}\text { Delphi Panel Added Statements on the elements/segments of quality } \\
\text { standards }\end{array}$ & $\begin{array}{l}\text { Agreement } \\
\text { Level }\end{array}$ & $\begin{array}{c}\text { Achieved } \\
\text { Consensus? }\end{array}$ \\
\hline $\begin{array}{l}\text { In the end it is a negotiated service/quality level and specific price that matters } \\
\text { most }\end{array}$ & $84.8 \%$ & Yes \\
$\begin{array}{l}\text { The weakest points of the supply chain are the information flow especially } \\
\text { in the case of deviations in good time to the right recipient. Solving this } \\
\text { could contribute to a more efficient service at the interfaces of the supply } \\
\text { chain }\end{array}$ & $84.8 \%$ & Yes \\
$\begin{array}{l}\text { Quality management is an integral part of management. If we are trying to } \\
\text { introduce something specific, then it will fail. }\end{array}$ & $60.9 \%$ & No \\
$\begin{array}{l}\text { The use of TEU's, pallets etc. reflects some aspect of standardisation. As a } \\
\text { result, standardisation already occurs without intervention. However, as } \\
\text { there are varying standards between different modes some government } \\
\text { assistance could help reduce these barriers. Providing assistance in } \\
\text { determining quality indicators between modes will also provide a similar } \\
\text { benefit to reducing barriers to uptake. }\end{array}$ & $45.7 \%$ & Divided \\
$\begin{array}{l}\text { It is important for the user to carefully examine the players before } \\
\text { contracting - in this respect a quality labelling system might be of value, } \\
\text { but this can also be dealt with by ISO 9001/14001. }\end{array}$ & $56.5 \%$ & No
\end{tabular}


Table 11 Second round Delphi on the issue of a new or modified standard

\begin{tabular}{lccc}
\hline Delphi Panel Added Statements & Agreed & Disagreed & No Comment \\
\hline $\begin{array}{l}\text { One single set of (aligned) standards would be good } \\
\text { A new or modified standard is not necessary, ISO and maybe other } \\
\text { standards have a very static approach and rarely encourage new } \\
\text { standard developments }\end{array}$ & $47.8 \%$ & $21.7 \%$ & $30.4 \%$ \\
$\begin{array}{l}\text { Yes a new or modified standard specifically focussed on transport } \\
\text { that enables companies to show their commitment to sustainable } \\
\text { solutions. }\end{array}$ & $43.5 \%$ & $23.9 \%$ & $32.6 \%$ \\
$\begin{array}{l}\text { No need of a new or modified standard. There are already too many } \\
\text { rules. The problems are not the rules but the application beyond } \\
\text { the image game. }\end{array}$ & $37.0 \%$ & $30.4 \%$ & $32.6 \%$ \\
$\begin{array}{l}\text { Yes a new or modified standard with well defined public KPIs would } \\
\text { ensure the service level }\end{array}$ & $34.8 \%$ & $32.6 \%$ & $32.6 \%$ \\
$\begin{array}{l}\text { A new or modified standard is necessary, the best practice example is } \\
\text { supply chain security ISO } 28000\end{array}$ & $21.7 \%$ & $30.4 \%$ & $47.8 \%$ \\
\hline
\end{tabular}

- A flexible quality code that will allow the users to define (with KPIs) their requirements could be a solution for the future.

It has already been noted that the Delphi panel was highly dominated by the participation from The Netherlands, United Kingdom, Belgium, Germany and Austria (see Fig. 1). However, we do not believe that this distorts the survey, as logistics is an international business, heavily dominated by Benelux, UK and German enterprises. Similar dominance of a few countries in another Delphi Study on 'Logistics Futures' is noted by McKinnon and Forster [28], stating that: 'A total of 176 specialists from six European countries contributed to this survey. Approximately half the respondents were based in the UK and the Netherlands.' The panels of the current study are experienced professionals with good representation of differing profile types and the workshop validated the Delphi study results as applicable across the EU. It may be unsafe to accept the view of the SMEs as indicative of small and medium transport service-providers, since $41 \%$ were from research organisations (academic, consultancy, research centre) and only $27 \%$ from transport or logistics service providers. The panel were multi-nationals and therefore multi-lingual, but since the early research showed that logistics is an international business and largely carried out in English, we proceeded with an English language study. This could be a useful area for follow up research and evaluation.

Following the desktop research and the initial telephone interviews, this research focused on EU level standards. The results are non-radical and they adopt a mixed market liberal economic view that looks for basic levels of state intervention, based on security and environmental issues. The most radical viewpoint is that the internalisation of externalities is a key part of the state's role, which in the transport policy community is not a new concept. The vision is not that different from the EU we know today. Regarding the necessity for a new freight transport and logistics quality standard in Europe, the study, through desktop research, interviews, Delphi study as well as validation workshop, does not suggest adopting a new standard.

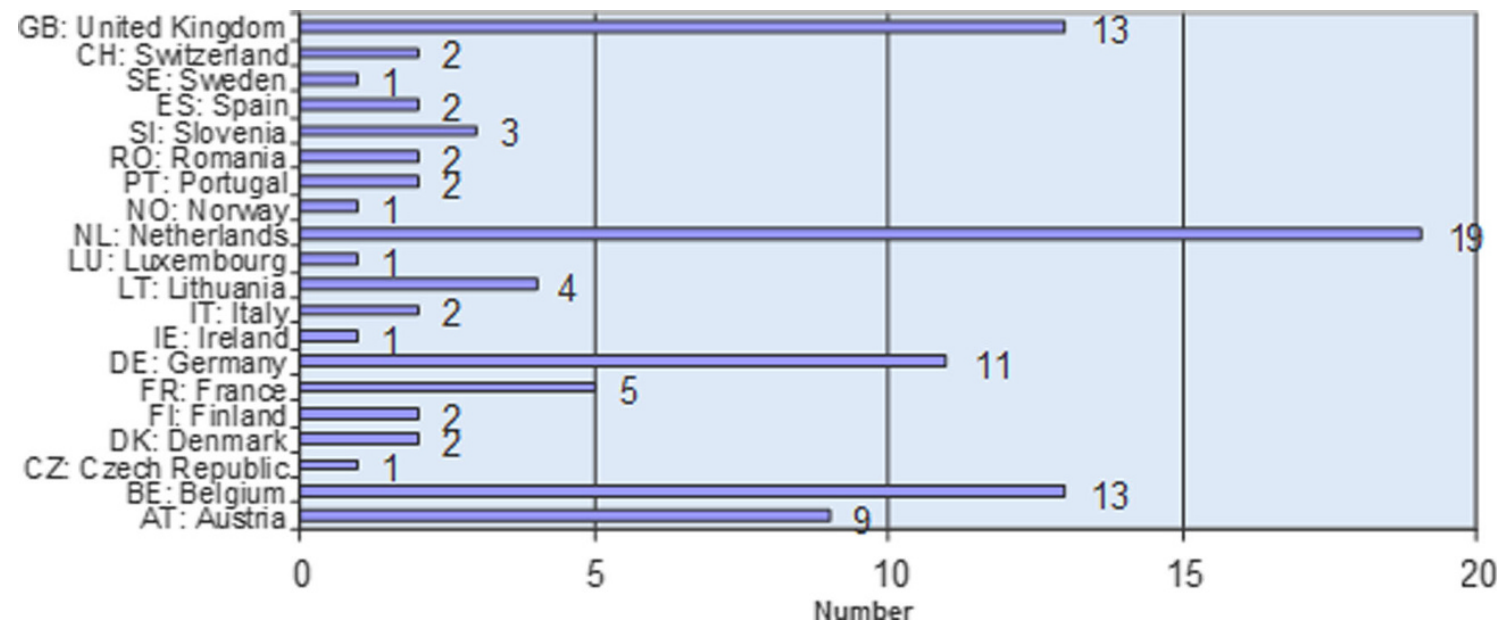

Fig. 1 Delphi panel categorised by country 
At all stages i.e. desktop research, interviews with experts, two rounds of Delphi study, and validation workshop, the experts consulted were divided on the final issue i.e. whether or not a new or modified standard is needed. However, no clear pressing need for one emerged. Given that the CEN process is clearly intended to respond to market/industry demand, that BestLog [5] recorded many active and disparate initiatives tailored to local and sectoral needs, and that our expert panel did not express or know of any demand, we conclude that there is no market demand for new standards and this is an area where subsidiarity is appropriate and functional.

However, a note of caution is worth making. Delphi surveys can be prone to supporting the status quo, and the results of this research are indeed quite non radical. This might suggest that further research using different methods would be helpful to test the results. On the other hand a piece of research that renders a largely negative answer is as valuable as one suggesting change or action. One should not forget that the development and implementation of regulation, standards and certification uses resources and it is better to be well informed of the need before embarking on incurring such costs. To that end we are happy to make quite nuanced conclusions and recommendations.

\section{Conclusion}

Considering the potential users of the current research outcome, the study concludes with recommendations for two sets of stakeholders: policy makers and freight transport and logistics service users.

\subsection{Recommendations for policy makers}

The research leads us to recommend:

That where a relatively fair and free market exists and there is not excessive dominance by any party or sector over another, quality is handled best through:

- Mutual agreement between parties, on a contract by contract basis;

- The use of ISO 9001 to develop, monitor and improve quality processes;

- The use of ISO 140001 to develop, monitor and improve quality processes;

- Facilitation of quality cultures within logistics training and continuous professional development;

- Support for the development of industry specific standards where appropriate, e.g. SQAS; and

- Initiatives to disseminate the existing CEN standards on logistics and supply chains.
Where there is an imbalanced market:

- Intervention to support the development of template quality codes is appropriate to support the balancing of customer and supplier in sectors where there is a significant distortion or imbalance, e.g. provision of infrastructure or oligopolistic sectors such as railfreight;

- There is no current industry demand for new standards; the ones that exist are not widely known and a functional trinity of ISO 9001, ISO 140001 and ISO 28000 exists. Therefore we see no need for a new or modified standard.

\subsection{Recommendations for service users and providers}

Service providers and users are recommended to use a mutually agreed contract with clearly defined KPIs. Use, by a large number of logistics service providers and users, of a certain format of contract with clearly defined KPI's, may come up with an idea to develop a standard to ensure quality, for the industry in general or for a particular field. For this, they will need to share their experiences of using such contracts. They may request national or European Commission funding to develop such a standard.

Acknowledgement The authors would like to thank the European Commission for part-funding this research under Framework Programme Seven, within the project "BE LOGIC: Benchmarking Logistics for Comodality." The authors would also like to thank all BE LOGIC project partners and online survey participants - without whom the research would not be a success - for taking part in the survey, workshop and for generating opinions in the research. However, the content and the opinion expressed in this article are the full responsibility of the authors.

Role of the funding source The need for this research was identified by the EU Freight Transport Logistics Action Plan [18] and published as an open competitive call under the Framework Programme Seven of the EU. The proposals were evaluated independently. The European Commission funded the wider BE LOGIC project, negotiated and agreed a Description of Work for the whole of the project, of which this research is part, approved the general scope of the study design and had no role in the collection, analysis, and interpretation of data, in the writing of the report, nor in the decision to submit the paper for publication.

Open Access This article is distributed under the terms of the Creative Commons Attribution License which permits any use, distribution, and reproduction in any medium, provided the original author(s) and the source are credited.

\section{References}

1. Abdel-Fattah N (1997) Road Freight Privatisation in Egypt A Comparative Analysis with Great Britain and Hungary. Unpublished Thesis for PhD, University of Plymouth, UK, pp 1-313

2. Abdel-Fattah N, Gray R, Cullinane S (1999) Road Freight and Privatisation: the Case of Egypt. Ashgate, UK, pp 1-50 
3. Ariel A (1989) Delphi forecast of the Dry bulk shipping industry in the year 2000. Marit Policy 16(4):305-336

4. Bardecki M (1984) Participants' response to the Delphi method: an attitudinal perspective. Technol Forecast Soc Chang 25:281-292

5. BestLog (2006), WP7: Development of a Label/Certificate, p. 6

6. BestLog (2011) State of the Art Report III, 3rd Edition, pp. 28-30, available at http://www.bestlog.org [last visited on March 2011, 15th]

7. Bureau Veritas (2012) ISO 28000 Certification, in http://www. bureauveritas.com, last visited September 2012, 25th

8. CEN - European Committee for Standardisation, 2012, Transport Logistics and Services - Published standards, in http://www.en.eu/ cen/sectors last visited September 2012, 25th

9. CER-UIC-CIT (2003) Freight Quality Charter, CER General Assembly, Rome, July

10. Chaffin WW, Talley WK (1980) Individual stability in Delphi studies. Technol Forecast Soc Chang 16(1):67-73, available at: http:// dx.doi.org/10.1016/0040-1625(80)

11. Clark A, Friedman M (1982) The relative importance of treatment outcomes. Evaluation Reviews 6(1):79-93

12. Dalkey, N. C. (1969) Delphi Method: An Experimental Study of Group Opinion, The Rand Corporation, The U.S

13. Dajani J, Talley WK, Sincoff MZ (1979) Stability and agreement criteria for the termination of Delphi studies. Technol Forecast Soc Chang 13(1):83-90, available at: http://linkinghub.elsevier.com/ retrieve/pii/0040162579900076

14. Erffmeyer R, Erffmeyer E, Lane I (1986) The Delphi technique: an empirical evaluation of the optimal number of rounds. Group and Organisation Management 11(1/2):120-129

15. European Commission (2006) Keep Europe Moving- Sustainable mobility for our continent: Mid-term review of the European Commission's 2001 White Paper [COM (2006) 314 final]

16. European Commission (2001) White Paper - European Transport Policy for 2010: time to decide, Directorate-General for Energy and Transport

17. European Commission (2004) Regulation No 261/2004 of the European Parliament and of the Council, available at http://ec. europa.eu/transport/passengers/air/doc/neb/questions_answers.pdf reg_2004_261.pdf [last accessed on June 2012, 26th]

18. European Commission (2007) Freight transport logistics Action Plan, Brussels: Commission of the European Communities, 18th October, available at http://ec.europa.eu/transport/logistics/freight_logistics action_plan/doc/action_plan/2007_com_logistics_action_plan_en. pdf. [last retrieved on March 2011, 15th]

19. Fabbe-Costes N, Jahre M, Rouquet A (2006) Interacting standards: a basic element in logistics networks. Int J Phys Distrib Logist Manag 36(2):92-111

20. Green H, Hunter C, Moore B (1990) Assessing the environmental impact of tourism development - Use of the Delphi technique. Tour Manag 11(2):111-120

21. GS1, 2008, Standard International Logistic Label - STILL, GS1 Logistic Label, Blue Tower, Avenue Louise 326, b10, B - 1050 Brussels, Belgium

22. Gustafson D, Shukla R, Delbecq A, Walster G (1973) A comparative study of differences in subjective likelihood estimates made by individuals, interacting groups, Delphi groups, and nominal groups. Organisational Behaviour and Human Performance 9:280-291
23. Ho SKM (1995) Is the ISO 9000 series for total quality management? Int J Phys Distrib Logist Manag 25(1):51-66

24. Hwang, K. S. (2004) A Comparative Study of Logistics Services in the Container Liner Shipping Market in the U.K. and South Korea. Unpublished thesis for PhD, Business School, University of Plymouth, 2004

25. Islam DMZ, Dinwoodie J, Roe M (2006) Promoting development through multi-modal freight transport in Bangladesh. Transport Reviews, ISSN 0144-1647 26(5):571-591

26. Kapoor P (1987) A system approach to documentary maritime fraud. Unpublished Thesis for PhD, University of Plymouth, UK, pp $1-408$

27. Liu, X. Grant, D.B. McKinnon, A.C. Fen, Y. (2010) An empirical examination of the contribution of capabilities to the competitiveness of logistics service providers A perspective from China. International Journal of Physical Distribution \& Logistics Management, MCB University Press, Vol. 40, No. 10, 847-866

28. McKinnon A, Forster M (2000) European Logistical and Supply Chain Trends: 1999-2005- Full Report of the Delphi 2005 Survey TRILOG project report. Logistics Research Centre, Heriot-Watt University, July, pp 1-19

29. Morash EA, Dröge C, Vickery S (1997) Boundary-spanning interfaces between logistics, production, marketing and new product development. International Journal of Physical Distribution \& Logistics Management, MCB University Press 27(5/6):350-369

30. Nelms K, Porter A (1985) An interactive Delphi method. Technol Forecast Soc Chang 28:43-61

31. Padilla C, Villalobos P, Spiller A, Henry G (2006) Consumer preference and willingness to Pay for an officially certified quality label: implications for traditional food producers. Agricultura Técnica (Chile), (July-September) 67(3)):300-308

32. Saldanha J, Gray R (2002) The potential for British coastal shipping in a multimodal chain. Maritime Policy and Management 29(1):7792

33. Sohal AS, Robert Millen R, Michael Maggard M, Moss S (1999) Quality in logistics: a comparison of practices between Australian and north american/european firms. Int J Phys Distrib Logist Manag 29(4):267-280

34. Stuter, L. (1998) Using the Delphi Technique to Achieve Consensus. Education Reporter, available at http://www.eagleforum.org [last accessed in October 2004), November, 1-4

35. The ISO14000 Environmental Management Group (2002) ISO 14000/ISO 14001 Environmental Management Guide, in http:// www.iso14000-iso14001-environmental-management.com/us.htm. last visited September, 25th

36. Transport for London (2014) Freight Operators Recognition Scheme, available at http://www.tfl.gov.uk/corporate/terms-and-conditions/ fors\#on-this-page-0 [last visited on 29th May 2014]

37. UIC -Freight Department (2009) Guide Quality of rail freight transport, ISBN: 978-2-7461-1639-9, April, available at http://www.uic. org/etf/publication/publication-detail.php?code_pub=190_01 [last visited on 15th March 2011]

38. Wellington, J. (2003) Educational Research - Contemporary Issues and Practical Approaches, UK: Continuum, Reprinted, pp 15-20 